basketball player. A great lover of the arts, especially of modern painting, theatre, and ballet, he also found much enjoyment in travel; in particular he took pleasure in sharing these activities in his later life in the company of his second wife, Gladys. He heeded little the counsel of those friends who suggested that his driving life-style was scarcely a recipe for longevity, but he lived a full and rich life with neverflagging zest for new ideas and schemes, coupled with a broad imagination and flair for accomplishment. His achievements in exploring and expounding on the most widespread group of natural products, the carbohydrates, in all of their aspects, have left a permanent impression on scientific history.

In addition to his wife, Gladys, living at their home in Jamesburg, New Jersey, Professor Pigman is survived by a brother and a sister, his sons, John and James, and daughter Jean of his first marriage, and three grandchildren.

Derek Horton

\section{H. E. Street}

Professor H. E. Street of the Department of Botany of the University of Leicester died on 4 December 1977, aged 64. The news of his death will sadden a wide range of scientists, in the U.K. and abroad, his academic colleagues and a large number of former students, research associates and many friends. Their collective sense of loss will be more acute in that the end was so unexpected.

Professor Street was in what was expected to be the last year of his active Professorship but it was known that he was planning for some more years of laboratory work in the field of his current interests. These interests fall into that area of plant physiology and of the study of growth which utilises aseptic conditions to culture erstwhile mature and quiescent tissue, to make it grow rapidly again, and whether from randomly proliferating explanted tissue or cells, to induce the development of new plants.

Professor Street's enthusiasm for this aspect of botanical work expressed itself, not only in a steady stream of research papers in the scholarly journals but also by his participation in symposia on the international level. At least as early as 1956 at Woodstock in Vermont, U.S.A. and in 1961 in Delhi, India and almost annually since then, Professor Street has been an invited guest and honoured contributor to such meetings. But more recently he lent his support to the organisation of such conferences, in part through the International Plant Tissue Culture Association which he helped to found. One such conference, widely attended at
Leicester in 1974, owed much of its success to his initiative and, in that case, he edited the resultant volume.

Throughout his career Professor Street actively fulfilled his desire to communicate science-to students and teachers whose understanding of basic biological science he cultivated and to a larger general audience who sought to comprehend the science and relate it to technology and society. He served a term as President of the Botanical Section of the British Association for the Advancement of Science, and always enjoyed demonstrating his work at scientific meetings such as those of the Society for Experimental Biology and, on occasion, at Royal Society Conversaziones.

In these various roles Professor Street was an inveterate traveller to botanical conferences whether they were large (like the last International Botanical Conference at Leningrad in 1975) or smaller (like the symposium on Plant Cell and Tissue Culture at Columbus, Ohio as recently as September 1977). At these gatherings his somewhat shaggy mane (whitening and thinning with the years) his cheerful laugh and the inevitable pipe (always being relit but never, it seemed, completely so) and his indefatigable attendance through the dullest sessions, which by his presence and questions he so of ten lightened, will be a memory that many will cherish.

Professor Street's most infectious quality was zest; an enthusiasm for the subject of botany that he always retained. But this emerged after he came to academic botany later than most. He trained first in pharmacy then obtained an external degree from London in 1939 with 1st class honours while still working at Nottingham. A Ph.D., at Birkbeck College, from London University was taken not only under the difficutlies of part-time study while being employed, but also amid the disturbances of World War II, for his research had to be moved first to his home (anticipating the wartime fate that eventually overtook the laboratory in Central London) and then to Manchester.

Professor Street's early interests involved the nitrogen metabolism of plants, and he maintained close contact with this subject for some years, but later he concentrated on the areas that finally captured his interest and loyalty. This began when he turned to the aseptic culture and nutrition and the indefinite growth of isolated root tips in liquid, at Manchester University after the completion of his doctoral degree. He was awarded a D.Sc in 1953.

Later, at Swansea, where he was to serve for 13 years as Professor of Botany in the University of Wales, Professor Street transformed the
Botany Dept. of the University College of Swansea for he presided over the building of well equipped botanical laboratories and made them an internationally known centre for the study of growth. But he sought association with a larger group of biologists and so moved to the University of Leicester.

Though one feared that an increasing administrative responsibility (he became the first Chairman of a School of Biology there) would have dampened his research ardour, this did not occur for he maintained his enthusiasm to the end. He will be sorely missed, not only by his wife and three children to whom our sympathy is extended, but as a teacher, research worker and as a protagonist for botanical science wherever botanists and plant physiologists study the problems of growth and form.

F. C. Steward

\section{Ana Conea}

Dr Ana Conea died on 4 March, 1977 in the great Bucharest earthquake. She was a leading Romanian soil scientist who had achieved particular success in the fields of soil classification and systematics. The Bucharest earthquake claimed many lives and the loss of Dr Conea, aged only 54, was particularly tragic.

She was born on $20 \mathrm{July}, 1922$ and graduated in geography from Bucharest State University in 1945. In 1966 she received her doctors degree for her work on pedogenetical formations and Quaternary deposits in central and northern Dobrudja, and this formed the basis for the book Formatiuni Cuaternare in Dobrogea which was published in 1970 by Editura Academiei, Bucharest. She also produced Guidebook 10 of the Romanian Geological Institute which deals with the loess in Romania.

Dr Conea was an active member of the Internationale Quartärvereinigung (INQUA) Loess Commission and provided the Romanian data for the INQUA loess map of Europe which is one of the Commission's major undertakings. She was also a member of the Paleopedology Commission of the International Society of Soil Science and of the ECA/FAO Group for the 1: 1.000,000 Soil Map of Europe. She published more than 90 papers during her 26 years work at the State Committee of Geology, the Geological Institute, and latterly at the Research Institute of Soil Science and Agrochemistry. She worked on the geography of Romanian soils, complex soil survey, paleopedology and paleogeography. Her main interests were in the fields of soil classification and syste- 
matics and she was the main author of the new Romanian soil classification system.

Her work had a continental as well as a national significance and her death leaves the European community of soil scientists and loess investigators perceptibly impoverished.

I. J. Smalley

\section{Arthur Erdélyi}

Arthur Erdélyi, FRS, Professor of Mathematics in the University of Edinburgh, died suddenly at his home on 12 December 1977 at the age of 69.

Professor Erdélyi was a mathematician of immense talent and earned an international reputation for his research in many aspects of mathematical analysis.

He had, by any standards, a remarkable life. He lived in Eastern Europe until his early thirties when he was forced as a Jew to leave, in mortal danger, and seek refuge in Britain in 1939. Due largely to the good offices of the late Sir Edmund Whittaker, he was able to settle in Edinburgh and work in the university there. In the late 1940 s he was attracted to California but fifteen years later he returned to the University of Fdinburgh as Professor of Mathematics, a position he filled with great distinction until his death.

The fifteen years he spent at the California Institute of Technology constituted the period at which his mathematical talents were at their height. He had gone originally to examine the research notes of the late Professor Harry Bateman on Special Functions and subsequently led a team of analysts to produce an integrated record based on his work. The resulting five volumes of the "Bateman Project", three on the properties of Special Functions and two devoted to tables of Integral Transforms, will almost certainly be regarded as the final definitive treatment of this topic.

It is not, however, for this that Arthur Erdélyi would like to be mainly remembered. Important as the applications of Special Functions were and are, there was a danger of the subject degencrating into sterile manipulations. In addition, the advance of computer technology had made less important the detailed properties of the functions themselves. It was therefore appropriate that, having produced the complete survey of the subject, Arthur Erdélyi should turn his powerful analytical mind to other fields.

There were two topics in particular in which important developments occurred in the early 1950s and with which Erdélyi became deeply involved, then and subsequently. The first was a systematic and rigorous approach to generalised functions, a topic envisaged by the pragmatic approaches of Heaviside and Dirac, and first given a proper framework by Schwartz. The second was the modern theory of singular perturbations, strained coordinates and matched asymptotic expansions in which mathematicians at the California Institute of Technology were particularly active. Erdélyi became known internationally as an expert in these fields although there were many other areas in which he worked actively and effectively.

From 1964 until his death, he was Professor of Mathematics at Idinburgh University. He returned to a department which had been dominated for over 50 years by the great names of Whittaker and Aitken and was to prove a worthy successor. The department flourished under his leadership, helped, as he was the first to acknowledge, by the cooperation of old and new colleagues alike.

Perhaps the most abiding memory of him which his mathematical colleagues will cherish was the remarkable breadth of his knowledge. He was able to talk with authority on almost any topic in mathematics and his commentaries were often laced with anecdotes and personal recollections and always given in impeccable English.

Outside his mathematics, he had a great love of music and of all things artistic. He was a man of ready wit and great personal charm. His many friends all over the world feel a sense of deep loss at his death but will ever recall with pleasure the privilege of having known him.

\section{A. G. Mackie}

\section{Christopher Goetze}

Christopher Goetze, Associate Professor of Geology at M.I.T., died on 21 November, 1977 at the age of 38 . He received his training at Harvard, obtaining the AB in Physics in 1961 and Phl in Geophysics in 1969. His doctoral studies were carried out with Francis Birch on attenuation in salt mixtures.

During his eight years at M.I.T., Goetze and his associates became one of the world's leading groups in the study of the rheology of rocks. They extended the creep measurements of olivine to temperatures as high as $1700{ }^{\circ} \mathrm{C}$ and to stresses as low as 50 bars. These were very important developments, for it enabled the flow law of olivine-..the most important constituent in the upper mantle-to be determined rather accurately for the first time at upper mantle conditions.
The mechanism of plastic flow of rocks at high temperature involves dislocation motion. Goetze and his associates pioneered techniques of dislocation identification. For example, they so improved the resolution using the transmission electron microscope that lattice planes in olivine or pyroxene could be directly imaged for the first time. They discovered that collapse of dislocation loops provided a measure of diffusion in olivine. They also discovered a simple way of decorating dislocations in olivine to make them visible optically. They showed for the first time a clear distinction between creep associated with dislocations and that associated with stress corrosion.

Goetze showed how dislocation theory combined with laboratory calibration experiments could be used to measure paleostresses in ancient deformed rocks. His establishment of a paleostress scale for quartz, olivine, and calcite gave structural geologists for the first time a measure of the stress active during the geological deformation of these minerals.

In 1971 Goetze suggested the use of ion thinning to expose microcracks in rocks for direct examination. This opened up a whole new field. Several groups now map cracks, using this technique, with such diverse applications as geothermal energy extraction, and earthquake prediction.

Goctze was a brilliant experimentalist with a keen understanding of the physics of deformation. His laboratory became recognised worldwide. A number of foreign scientists were attracted here for sabbatical visits. $\mathrm{He}$ was an invited lecturer at the Royal Society in I.ondon in 1977 and at the NATO Advanced Institute Summer School in Geophysics at Cargese, Corsica, in the summer of 1976. He was also invited lecturer at a number of Penrose and Chapman conferences and was to have lectured at a conference on the physics of magmatic processes at Princeton in November 1977. During the last couple of years he had been able to extend the laboratory results to a number of major geophysical problems such as the stress near plate boundaries, the role of shear heating in the upper mantle, the role of volatiles and melt in upper mantle flow, and the mechanical history of certain meteorites.

A noted mountain climber, Goetze established new routes on Mount McKinley and in the Hayes range in Alaska, the Wind River Range in Wyoming, in British Columbia, and in Labrador. He cruised the waters of Newfoundland and Northern Labrador in a small sailboat and in a kayak for many years on vacations with his family.

W. F. Brace 